\title{
Characterization of denitrifying activity by the alphaproteobacterium, Sphingomonas wittichii RW1
}

\author{
Lynnie S. Cua ${ }^{1+}$ and Lisa Y. Stein ${ }^{2 *}$ \\ ${ }^{1}$ Department of Environmental Sciences, University of California, Riverside, CA, USA \\ ${ }^{2}$ Department of Biological Sciences, Faculty of Science, University of Alberta, Edmonton, AB, Canada
}

\author{
Edited by: \\ Martin G. Klotz, University of North \\ Carolina at Charlotte, USA \\ Reviewed by: \\ Asa Frostegard, Norwegian \\ University of Life Sciences, Norway \\ James Moir, University of York, UK \\ *Correspondence: \\ Lisa Y. Stein, Department of \\ Biological Sciences, Faculty of \\ Science, University of Alberta, CW \\ 405 Bio Sci Centre, Edmonton, $A B$, \\ Canada \\ e-mail: lisa.stein@ualberta.ca \\ tPresent address: \\ Lynnie S. Cua, County of San Diego, \\ Department of Environmental \\ Health, Vector Disease and \\ Diagnostic Laboratory, San Diego, \\ CA, USA
}

Sphingomonas wittichii RW1 has no reported denitrifying activity yet encodes nitrite and nitric oxide reductases. The aims of this study were to determine conditions under which S. wittichii RW1 consumes nitrite $\left(\mathrm{NO}_{2}^{-}\right)$and produces nitrous oxide $\left(\mathrm{N}_{2} \mathrm{O}\right)$, examine expression of putative genes for $\mathrm{N}$-oxide metabolism, and determine the functionality of chromosomal (ch) and plasmid ( $p$ ) encoded quinol-dependent nitric oxide reductases (NorZ). Batch cultures of wildtype (WT) and a nor $Z_{\text {ch }}$ mutant of $S$. wittichii RW1 consumed $\mathrm{NO}_{2}^{-}$and produced $\mathrm{N}_{2} \mathrm{O}$ during stationary phase. The nor $Z_{\text {ch }}$ mutant produced $\mathrm{N}_{2} \mathrm{O}$, although at significantly lower levels (c.a. $66-87 \%$ ) relative to the WT. Rates of $\mathrm{N}_{2} \mathrm{O}$ production were 2-3 times higher in cultures initiated at low relative to atmospheric $\mathrm{O}_{2}$ per unit biomass, although rates of $\mathrm{NO}_{2}^{-}$consumption were elevated in cultures initiated with atmospheric $\mathrm{O}_{2}$ and $1 \mathrm{mM} \mathrm{NaNO}$. Levels of mRNA encoding nitrite reductase (nirK), plasmid-encoded nitric oxide dioxygenase $\left(h m p_{p}\right)$ and plasmid-encoded nitric oxide reductase $\left(n o r Z_{p}\right)$ were significantly higher in the nor $Z_{c h}$ mutant over a growth curve relative to WT. The presence of $\mathrm{NO}_{2}^{-}$further increased levels of nirK and $h m p_{p}$ mRNA in both the WT and nor $Z_{c h}$ mutant; levels of nor $Z_{p}$ mRNA compensated for the loss of nor $Z_{\text {ch }}$ expression in the $n o r Z_{\text {ch }}$ mutant. Together, the results suggest that $S$. wittichii RW1 denitrifies $\mathrm{NO}_{2}^{-}$to $\mathrm{N}_{2} \mathrm{O}$ and expresses gene products predicted to detoxify $\mathrm{N}$-oxides. So far, only $S$. wittichii strains within four closely related taxa have been observed to encode both nirK and norZ genes, indicating a species-specific lateral gene transfer that may be relevant to the niche preference of $S$. wittichii.

Keywords: Sphingomonas wittichii RW1, nitrous oxide, nitrite reductase, nitric oxide reductase, nitric oxide dioxygenase, denitrification

\section{INTRODUCTION}

Denitrification is the sequential reduction of nitrate $\left(\mathrm{NO}_{3}^{-}\right)$and nitrite $\left(\mathrm{NO}_{2}^{-}\right)$to dinitrogen $\left(\mathrm{N}_{2}\right)$ via the gaseous intermediates, nitric oxide $(\mathrm{NO})$ and nitrous oxide $\left(\mathrm{N}_{2} \mathrm{O}\right)$ (Zumft, 1997). Respiratory denitrification is considered an anaerobic energygenerating metabolism; however, many bacteria can denitrify in the presence of $\mathrm{O}_{2}$ starting with $\mathrm{NO}_{3}^{-}$or $\mathrm{NO}_{2}^{-}$and terminating with $\mathrm{N}_{2} \mathrm{O}$ due to inhibition or absence of nitrous oxide reductase (Philippot et al., 2011; Stein, 2011; Chen and Strous, 2013). While some denitrifiers grow via hybrid respiration with $\mathrm{O}_{2}$ and $\mathrm{NO}_{3}^{-}$ and/or $\mathrm{NO}_{2}^{-}$, others respire $\mathrm{N}$-oxides during late-log to stationary phase for detoxification and/or energy conservation, particularly under reduced $\mathrm{O}_{2}$ (Takaya et al., 2003; Stein, 2011; Chen and Strous, 2013). The collective role of denitrifying bacteria in transformation and release of highly reactive $\mathrm{N}$-oxides is of critical importance because of the effects these molecules have on environmental and human health, atmospheric chemistry, and global warming (Fields, 2004; Galloway et al., 2008).

Sphingomonas wittichii RW1 was isolated from the River Elbe (Germany) as a model organism for studying the bioremediation of dioxin-containing compounds (Wittich et al., 1992; Wilkes et al., 1996; Yabuuchi et al., 2001; Keum et al., 2008). The complete genome sequence of $S$. wittichii RW1 revealed the presence of a single circular chromosome and two megaplasmids (Miller et al., 2010). Although not known to denitrify, S. wittichii RW1 encodes in its genome a copper-containing nitrite reductase (nirK) as the terminal member of a four-gene cluster with a NOresponsive NsrR regulator encoded upstream (Swit_1789-93). This gene cluster shares structural and sequence homology to ammonia- and nitrite-oxidizing bacteria in the Nitrosomonas and Nitrobacter genera, respectively (Cantera and Stein, 2007). S. wittichii RW1 also encodes a chromosomal (Swit_4614) and plasmid copy (Swit_5200) of quinol-linked nitric oxide reductase (nor $Z$ ). NorZ is often expressed in non-denitrifying pathogenic bacteria for NO detoxification (Hendriks et al., 2000), but can also act alongside the terminal oxidase in the aerobic respiratory chain for energy conservation (Chen and Strous, 2013). The plasmid-encoded nor $Z_{\mathrm{p}}$ (Swit_5200) is the terminal member of a four-gene cluster; the first member of which encodes a nitric oxide dioxygenase ( $h m p_{p}$; Swit_5203) with predicted function in $\mathrm{NO}$ oxidation to $\mathrm{NO}_{3}^{-}$or $\mathrm{NO}$ reduction to $\mathrm{N}_{2} \mathrm{O}$ depending on $\mathrm{O}_{2}$ concentration (Bonamore and Boffi, 2008). Nitric oxide dioxygenases are present in both denitrifying and nondenitrifying microorganisms to combat nitrosative and oxidative 
stresses (Bonamore and Boffi, 2008; Forrester and Foster, 2012). Although nitric oxide dioxygenases are usually conserved members of the NO-controlled NsrR transcriptional regulon in bacteria (Rodionov et al., 2005), the plasmid-encoded gene cluster in S. wittichii RW1 that includes both NorZ and nitric oxide dioxygenase is preceded by a CDS for the NO-responsive NnrR transcriptional regulator (Swit_5204). Aside from Swit_5203, S. wittichii RW1 encodes three other putative $h m p$ genes, the plasmid-encoded Swit_5299 and the chromosomal Swit_1434 and 3173. A comparison of 51 genome-sequenced sphingomonad strains (encompassing the Sphingomonas, Sphingobium, Novosphingobium, and Sphingopyxis genera) by BLAST searches through the Integrated Microbial Genomes database (http://img. jgi.doe.gov) revealed that only the two strains of $S$. wittichii (RW1 and DP58) encode the complete nirK gene cluster, whereas eight sphingomonad genomes encode either one or two copies of nor $Z$ and 17 genomes encode one or more $h m p$ genes whose translated sequences share $>60 \%$ protein identity to Swit_5203. Hence, the potential for spingomonad bacteria to transform nitrogen oxides appears to be fairly restricted.

Previous studies in Neisseria and Synechococcus demonstrated that disruption of nor $Z$ expression resulted in increased NO sensitivity, diminished $\mathrm{NO}$ consumption and $\mathrm{N}_{2} \mathrm{O}$ production, and decreased growth under anoxia (Householder et al., 2000; Busch et al., 2002). Interestingly, Ralstonia eutropha $\mathrm{H} 16$ also possesses two independent quinol-linked nitric oxide reductases. Deletion of either gene in R. eutropha $\mathrm{H} 16$ resulted in no phenotypic change under aerobic or anaerobic growth at the expense of $\mathrm{NO}_{3}^{-}$ or $\mathrm{NO}_{2}^{-}$(Cramm et al., 1997). Therefore, in the present study we tested the hypothesis that the norZ genes in S. wittichii RW1 are similarly isofunctional.

The overarching hypothesis of the present study is that $S$. wittichii RW1 reduces $\mathrm{NO}_{2}^{-}$to $\mathrm{N}_{2} \mathrm{O}$ and thus can be classified as a denitrifying strain. The ability of $S$. wittichii RW1 to denitrify from $\mathrm{NO}_{3}^{-}$was not investigated as the genome of S. wittichii RW1 encodes only the alpha subunit of assimilatory nitrate reductase (Swit_1709) and no features of dissimilatory nitrate reductases. Furthermore, this strain tested negative for reduction of $\mathrm{NO}_{3}^{-}$to $\mathrm{NO}_{2}^{-}$(Yabuuchi et al., 2001). There is no identifiable sequence in the genome with similarity to nitrous oxide reductase; hence, this strain is predicted to denitrify only $\mathrm{NO}_{2}^{-}$ to $\mathrm{N}_{2} \mathrm{O}$. To provide support for S. wittichii RW1 as a denitrifier, objectives were to: (a) determine whether and when S. wittichii RW1 produces $\mathrm{N}_{2} \mathrm{O}$ at the expense of $\mathrm{NO}_{2}^{-}$(b) investigate the regulation of putative $\mathrm{N}$-oxide metabolism genes in response to varying $\mathrm{NO}_{2}^{-}$, and (c) determine whether the chromosomal- and plasmid-encoded norZ genes in S. wittichii RW1 are isofunctional.

\section{MATERIALS AND METHODS CULTURE MAINTENANCE}

Sphingomonas wittichii RW1 was provided as a gift from Dr. Rolf Halden. Cultures were grown in $5 \mathrm{~mL}$ Luria-Bertani Broth (LB) in sterilized $15 \mathrm{~mL}$ capped-polystyrene tubes in a rotary shaker $(180$ r.p.m.) at $28^{\circ} \mathrm{C}$. Cultures were periodically streaked and grown on LB agar plates for single colony isolation to maintain culture purity.

\section{CONSTRUCTION OF nor $Z_{\text {ch }}$ MUTANT OF $\boldsymbol{S}$. WITTICHII RW1}

The region from bp 203 to 776 of the $n o r Z_{\text {ch }}$ gene was PCRamplified from $S$. wittichii RW1 genomic DNA with primers 203F $5^{\prime}$ aactggaacaggccgatg $3^{\prime}$ and 776R $5^{\prime}$ cgatcgccttcatcttcg $3^{\prime}$ to make use of an internal BclI restriction site [Primer3 Input 0.4.0 software (Rozen and Skaletsky, 2000)]. The amplification product was purified and ligated to the pGEM $^{\circledR}-\mathrm{T}$ Vector according to manufacturers' instructions (Promega Corp., Madison, WI). The ligation mixture was transformed into $\mathrm{dam}^{-} / \mathrm{dcm}^{-}$competent E. coli cells (New England BioLabs Inc., Ipswich, MA) and transformants were selected via blue-white screening on LB agar plates containing $0.5 \mathrm{mM}$ IPTG, $80 \mu \mathrm{g} / \mathrm{mL}$ X-Gal, and $100 \mu \mathrm{g} / \mathrm{mL}$ ampicillin. Plasmids from positive transformants were purified using Wizard ${ }^{\circledR}$ Plus SV Minipreps DNA Purification System kit (Promega Corp., Madison, WI) and digested with the BclI restriction enzyme (New England BioLabs Inc., Ipswich MA). The digest was run on a $0.8 \%$ agarose gel and linearized vector was gelpurified using the Wizard ${ }^{\circledR}$ SV Gel and PCR Clean-Up System kit (Promega Corp., Madison, WI).

A gentamycin-resistance cassette $(871 \mathrm{bp})$ was digested from the pUCGM vector (gift from N. Hommes) using the BamHI restriction enzyme (New England BioLabs Inc., Ipswich MA). The digest was gel-purified from a $0.8 \%$ agarose gel and ligated to the previously BclI-digested pGEM-T-nor $Z$ vector. The ligation mixture was transformed into competent E. coli JM109 cells. Transformed cells were plated onto LB agar containing $100 \mu \mathrm{g} / \mathrm{mL}$ ampicillin and $10 \mu \mathrm{g} / \mathrm{mL}$ gentamycin. Positive transformants were verified by PCR and Sanger sequencing using the BigDye Terminator Cycle Sequencing Kit (Applied Biosystems, Foster City USA). Plasmids containing the correct inserts were purified as described above and electroporated into S. wittichii RW1 cells using an E. coli Pulser ${ }^{\mathrm{TM}}$ Transformation Apparatus (BioRad Laboratories, Hercules, CA). Competent S. wittichii RW1 cells were prepared by harvesting in exponential phase, washing three times with $20 \mathrm{~mL}$ ice-cold and nuclease-free water, washing twice with $2 \mathrm{~mL}$ ice-cold $10 \%$ glycerol, and resuspended in $10 \%$ glycerol to a final volume of $100 \mu \mathrm{L}$. Electroporated cells were plated onto LB agar containing $10 \mu \mathrm{g} / \mathrm{mL}$ gentamycin. The $n o r Z_{\text {ch }}$ mutant strain was checked by PCR using additional primers: $45 \mathrm{~F} 5^{\prime}$ agagacccaggaccacgac $3^{\prime}, 854 \mathrm{R} 5^{\prime}$ tcaccgtcatggaatattgg $3^{\prime}$, pUCGM173F $5^{\prime}$ tgcctcgggcatccaagcagca $3^{\prime}$, pUCGM514R 5' gagagcgccaacaaccgcttct $3^{\prime}$ and pUCGM519F 5' cttacgttctgcccaggttt $3^{\prime}$. PCR products were purified and validated by Sanger sequencing. The nor $Z_{\mathrm{ch}}$ mutant strain was maintained on LB media with $50 \mu \mathrm{g} / \mathrm{mL}$ gentamycin.

\section{GROWTH EXPERIMENTS}

S. wittichii RW1 wildtype (WT) and nor $Z_{\text {ch }}$ mutant cells from exponentially growing cultures were inoculated into LB media $(500 \mu \mathrm{L}$ into $100 \mathrm{~mL})$ containing $0,0.3$, or $1 \mathrm{mM} \mathrm{NaNO}_{2}$ into glass serum bottles $(160 \mathrm{~mL})$, which were then crimp-sealed with rubber septa and aluminum seals. Incubations of nor $Z_{\mathrm{ch}}$ mutant cells contained $50 \mu \mathrm{g} / \mathrm{mL}$ gentamycin. Triplicate incubations of each control condition included the same concentrations of $\mathrm{NaNO}_{2}$ plus: (1) heat-inactivated cells, (2) no cells, or (3) live cells in bottles purged of $\mathrm{O}_{2}$ by sparging the medium with $\mathrm{N}_{2}$. All control incubations were treated identically to the 
experimental incubations to determine whether chemical decomposition of $\mathrm{NO}_{2}^{-}$contributed to $\mathrm{NO}_{2}^{-}$loss or $\mathrm{N}_{2} \mathrm{O}$ accumulation. Gas headspace $(60 \mathrm{~mL})$ was either left unchanged (atmospheric $\mathrm{O}_{2}$ ) or, for WT cells, sparged with $\mathrm{N}_{2}$ and injected with pure $\mathrm{O}_{2}$ prior to inoculation (ca. $3 \% \mathrm{O}_{2}$ in gas headspace as validated by gas chromatography; GC-TCD, Shimadzu, Kyoto, Japan; Molecular Sieve 6A column, Alltech, Deerfield IL). Experimental and control bottles were incubated in a rotary shaker (180 r.p.m.) at $28^{\circ} \mathrm{C}$. Starting at $t=0 \mathrm{~h}, 2 \mathrm{~mL}$ samples were extracted every $4 \mathrm{~h}$ using a sterile $1 \mathrm{~mL}$ needle and syringe. Growth was determined by measuring OD $600 \mathrm{~nm}$ using a Spectronic 20 Genesys spectrophotometer (Thermo Fisher Scientific, Inc., Waltham, MA). Cells were immediately treated with $500 \mu \mathrm{L}$ RNAprotect ${ }^{\mathrm{TM}}$ Bacteria Reagent (Qiagen, Valencia, CA), and kept at $-80^{\circ} \mathrm{C}$. Experiments consisted of five independent trials performed on different days for both strains and under every condition.

\section{NUCLEIC ACID EXTRACTION}

Genomic DNA was isolated using the Wizard ${ }^{\circledR}$ SV Genomic DNA Purification System kit (Promega Corp., Madison, WI). Total RNA was extracted using the Aurum ${ }^{\mathrm{TM}}$ Total RNA Mini kit (BioRad Laboratories, Hercules, CA). Nucleic acid concentration was determined using a NanoDrop ${ }^{\circledR}$ ND-1000 Spectrophotometer (Nanodrop Technologies, Inc., Wilmington, DE). DNA and RNA samples were kept at -20 and $-80^{\circ} \mathrm{C}$, respectively.

\section{DOT-BLOT HYBRIDIZATION}

Gene-specific primers were designed from CDS's of selected genes from the $S$. wittichii RW1 genome sequence (Genbank accession: CP000699 to CP000701) using Primer3 Input 0.4.0 software (Rozen and Skaletsky, 2000) (Table 1). PCR reactions included standard reagents for Taq polymerase and genomic DNA as template in $25 \mu \mathrm{L}$ reactions (Sambrook and Russell, 2001). Thermal cycler (iCycler, BioRad, Hercules, CA) amplification conditions were: $95^{\circ} \mathrm{C}$ for $5 \mathrm{~min}, 30$ cycles of $95^{\circ} \mathrm{C}$ for $40 \mathrm{~s}, 55^{\circ} \mathrm{C}$ for $40 \mathrm{~s}$ and $72^{\circ} \mathrm{C}$ for $50 \mathrm{~s}$, with an additional extension cycle of $72^{\circ} \mathrm{C}$ for $7 \mathrm{~min}$. PCR products were checked by agarose gel (1\%) to verify single products of appropriate size. Amplification products were purified using the Wizard ${ }^{\circledR}$ SV Gel and PCR Clean-Up System kit (Promega Corp., Madison, WI). Amplification products were labeled using the Prime-a-Gene labeling system (Promega Corp., Madison, WI) with $\left[\alpha-{ }^{32} \mathrm{P}\right]$-dCTP $\left(3000 \mathrm{Ci} \mathrm{mmol}^{-1}\right.$; PerkinElmer Inc., Waltham, MA) and random hexamers. The dynamic range of detection for each probe was tested using a concentration series of specific mRNA from 0.1 to $3 \mu \mathrm{g}$ from control incubations $(0 \mathrm{mM} \mathrm{NaNO} 2)$. The $\mathrm{r}^{2}$ values for the slope of hybridization intensity/ $\mu \mathrm{g}$ mRNA was from 0.94 to 1.0 for all probes.

Two $\mu \mathrm{g}$ total RNA from each sample was blotted onto a Zeta-Probe ${ }^{\circledR}$ GT nylon membrane (Bio-Rad Laboratories, Hercules, CA) using a Minifold ${ }^{\circledR}$ microsample filtration manifold (Dot-Blot System, Schleicher \& Schuell, Keene, NH) following the Zeta-Probe ${ }^{\circledR}$ protocol. Membranes were allowed to dry overnight and UV-crosslinked (FB-UVXL-1000, Fisher Scientific, Pittsburgh, PA). Prehybridization, hybridization, and washing of Zeta-Probe ${ }^{\circledR}$ nylon membranes were done according to manufacturer's instructions at $30^{\circ} \mathrm{C}$. To allow re-probing, membranes were stripped of radioactivity by washing twice in a $0.1 \times$ $\mathrm{SSC} / 0.5 \% \mathrm{SDS}$ solution at $95-100^{\circ} \mathrm{C}$ for $20 \mathrm{~min}$. All blots were hybridized to gene-specific probes to normalize hybridization signals to the 16S rRNA pool. Hybridization intensity was analyzed using a Typhoon Phosphorimager and Imagequant software (Amersham, Piscataway, New Jersey).

\section{DATA ANALYSIS}

Background and signal from non-specific binding was subtracted, after which the relative hybridization intensity of specific probes was normalized by dividing gene-specific signal by signal from $16 \mathrm{~S}$ rRNA probe hybridizations. The fold difference in levels of mRNA for each gene and time point was determined by dividing hybridization intensities from dot blots of RNA extracted from $\mathrm{NO}_{2}^{-}$amended by those from unamended cultures. Student's $t$-test $(p<0.05)$ was performed to determine significant differences between treatments.

\section{ANALYTICAL MEASUREMENTS}

Nitrite and ammonium were measured colorimetrically using standard methods (Clesceri et al., 1998). Nitrate was measured using a Standard Range Lab Nitrate Test kit (NECi, Lake Linden, Michigan). $\mathrm{O}_{2}$ and $\mathrm{N}_{2} \mathrm{O}$ were measured from the gas headspace of sample bottles by GC-TCD (Shimadzu, Kyoto Japan; Molesieve 5A and Hayesep Q columns, Alltech, Deerfield IL). Concentrations were determined by comparing to standard curves generated for each reagent and gas within the limits of detection.

Table 1 | Primers used to generate probes for RNA dot-blot hybridizations.

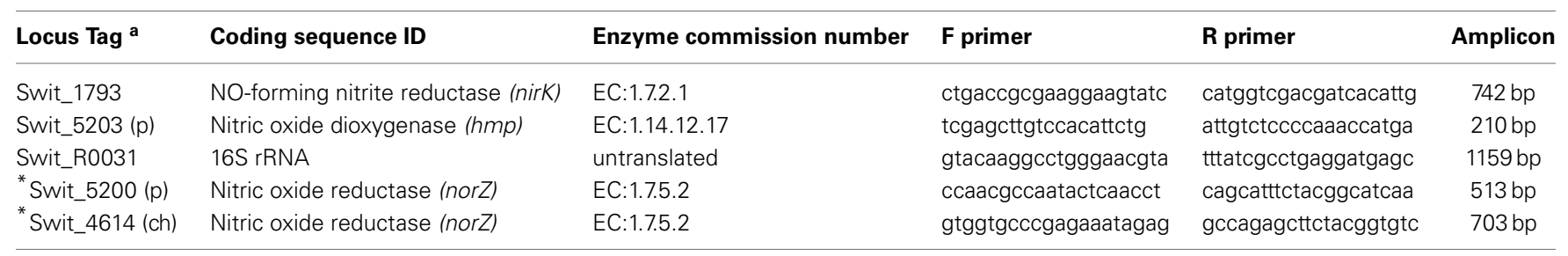

a Significant difference between atmospheric and reduced $\mathrm{O}_{2}$ for wildtype (WT) cultures incubated with the same concentration of $\mathrm{NaNO}_{2}$.

(p), encoded on plasmid; (ch), encoded on chromosome.

${ }^{*}$ Swit_4614 and Swit_5200 share 54\% amino acid sequence identity based on BLAST.

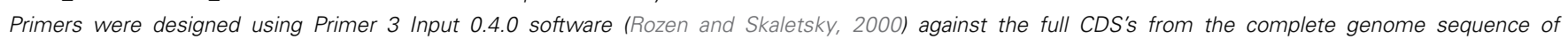
Sphingomonas wittichii RW1, which includes a single circular chromosome and two megaplasmids (Genbank accession: CP000699-CP000701). 


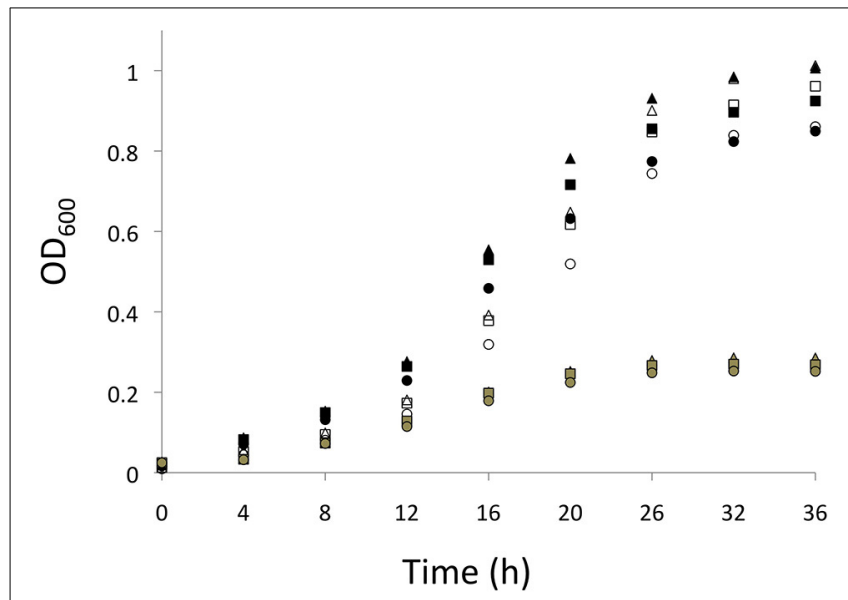

FIGURE 1 | Growth $\left(\mathrm{OD}_{600}\right)$ measured over time (h) for $S$. wittichii RW1 WT cultures initiated at atmospheric $\mathrm{O}_{2}$ (black symbols) or reduced $\mathrm{O}_{2}$ (gray symbols), and for $n$ or $B_{\text {ch }}$ mutant $S$. wittichii RW1 cultures initiated at atmospheric $\mathrm{O}_{\mathbf{2}}$ (white symbols). Triangles $=0 \mathrm{mM}$ added $\mathrm{NaNO}_{2}$, squares $=0.3 \mathrm{mM}$ added $\mathrm{NaNO}_{2}$, and circles $=1 \mathrm{mM}$ added $\mathrm{NaNO}_{2}$. Points on the growth curves represent averaged values from 5 independent experiments for each incubation condition.

\section{RESULTS}

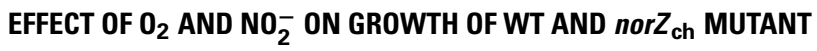 STRAINS OF S. WITTICHII RW1}

S. wittichii RW1 is an aerobic heterotrophic bacterium; hence, the doubling time (calculated from 12 to $20 \mathrm{~h}$ growth) and final yields of non-mutagenized cells were significantly faster and higher, respectively, for cultures initiated under atmospheric compared to reduced (ca. 3\%) $\mathrm{O}_{2}$ levels (Figure 1 and Table 2). Doubling times of the nor $Z_{\mathrm{ch}}$ mutant were significantly shorter than those of the WT during exponential growth; thus, even though the nor $Z_{\mathrm{ch}}$ mutant exhibited a longer lag phase, the cell density of the cultures were equivalent in stationary phase (Figure 1 and Table 2). The addition of $\mathrm{NaNO}_{2}$ to cultures initiated at atmospheric $\mathrm{O}_{2}$ only significantly increased the doubling time of WT cultures, but significantly reduced the final yields of both WT and nor $Z_{\mathrm{ch}}$ mutant cultures (Table 2).

\section{CONSUMPTION OF NO- AND PRODUCTION OF $\mathrm{N}_{\mathbf{2}} \mathrm{O}$}

Cultures of WT and nor $Z_{\mathrm{ch}}$ mutant $S$. wittichii RW1 were incubated in the presence of $\mathrm{NaNO}_{2}$ to assess whether expression of $n o r Z_{\mathrm{ch}}$ was required for aerobic denitrifying activity. Amounts of remaining $\mathrm{NO}_{2}^{-}$, remaining $\mathrm{O}_{2}$, and headspace $\mathrm{N}_{2} \mathrm{O}$ levels were compared over stationary phase (Table 3 ). $\mathrm{NO}_{2}^{-}$was consumed nearly to completion in both WT and nor $Z_{\mathrm{ch}}$ mutant cultures by $96 \mathrm{~h}$ incubation. Neither WT nor nor $Z_{\text {ch }}$ mutant cultures consumed $\mathrm{O}_{2}$ to complete anoxia and headspace $\mathrm{O}_{2}$ levels remained largely stable following $72 \mathrm{~h}$ incubation, even with continuous shaking at $180 \mathrm{rpm} . \mathrm{N}_{2} \mathrm{O}$ was measurable in the gas headspace starting after $48 \mathrm{~h}$ of incubation and continued to accumulate proportionally with the amount of added $\mathrm{NaNO}_{2}$ (Table 3). The nor $Z_{\text {ch }}$ mutant cultures produced significantly less $\mathrm{N}_{2} \mathrm{O}$ than the WT cultures (66-87\% of WT levels) at both $\mathrm{NO}_{2}^{-}$concentrations.
Table 2 | Growth of WT and nor $Z_{\text {ch }}$ mutant strains of $S$. wittichii RW1 at variable $\mathrm{NaNO}_{2}$ and $\mathrm{O}_{2}$ concentrations.

\begin{tabular}{|c|c|c|c|c|}
\hline \multirow{2}{*}{$\begin{array}{l}\text { Variable in growth } \\
\text { condition }\end{array}$} & \multicolumn{2}{|c|}{ Doubling time (h) } & \multicolumn{2}{|c|}{ Yield (OD600 nm) } \\
\hline & WT & nor $Z_{c h}$ & WT & nor $Z_{c h}$ \\
\hline $\begin{array}{l}\text { Atmospheric } \mathrm{O}_{2}, \text { no } \\
\mathrm{NaNO}_{2}\end{array}$ & $5.3^{\mathrm{abc}}$ & $4.4^{c}$ & $0.98^{a b}$ & $0.98^{b}$ \\
\hline Reduced $\mathrm{O}_{2}$, no $\mathrm{NaNO}_{2}$ & $8.2^{\mathrm{a}}$ & N.D. & $0.25^{\mathrm{a}}$ & N.D. \\
\hline $\begin{array}{l}\text { Atmospheric } \mathrm{O}_{2}, 0.3 \mathrm{mM} \\
\mathrm{NaNO}_{2}\end{array}$ & $5.6^{\mathrm{abc}}$ & $4.4^{c}$ & $0.90^{\mathrm{ab}}$ & $0.91^{b}$ \\
\hline $\begin{array}{l}\text { Reduced } \mathrm{O}_{2}, 0.3 \mathrm{mM} \\
\mathrm{NaNO}_{2}\end{array}$ & $8.5^{\mathrm{a}}$ & N.D. & $0.25^{\mathrm{a}}$ & N.D. \\
\hline $\begin{array}{l}\text { Atmospheric } \mathrm{O}_{2}, 1.0 \mathrm{mM} \\
\mathrm{NaNO}_{2}\end{array}$ & $5.5^{\mathrm{abc}}$ & $4.4^{c}$ & $0.82^{\mathrm{ab}}$ & $0.84^{b}$ \\
\hline $\begin{array}{l}\text { Reduced } \mathrm{O}_{2}, 1.0 \mathrm{mM} \\
\mathrm{NaNO}_{2}\end{array}$ & $8.4^{\mathrm{a}}$ & N.D. & $0.22^{\mathrm{ab}}$ & N.D. \\
\hline
\end{tabular}

Doubling times were calculated during exponential growth from 12 to $20 \mathrm{~h}$. Final cell yields were reported at 32 and $20 \mathrm{~h}$ growth when initiated at atmospheric (ca. 22\%) and reduced (ca. 3\%) $\mathrm{O}_{2}$ levels, respectively. Values represent averages from 5 separate experiments. Statistically significant differences between groups were determined by Student's t-test at $p<0.05$ and are designated as follows:

a Significant difference between atmospheric and reduced $\mathrm{O}_{2}$ for wildtype (WT) cultures only.

${ }^{b}$ Significant difference between $W T$ or nor $Z_{c h}$ mutant cultures incubated with $\mathrm{NaNO}_{2}$ relative to unamended controls.

c Significant difference between $W T$ and nor $Z_{\text {ch }}$ mutant cultures grown under identical conditions. N.D., not determined.

Nitrate production was not observed, which would be an expected aerobic activity of $\mathrm{Hmp}$. $\mathrm{NH}_{4}^{+}$concentrations also did not vary between treatment groups, which would be expected if $S$. wittichii RW1 reduced $\mathrm{NO}_{2}^{-}$directly to $\mathrm{NH}_{4}^{+}$and allowed its accumulation prior to assimilation (data not shown). $\mathrm{N}_{2}$ was not measured. Control incubations containing heat-inactivated cells, no cells, or live cells inoculated into bottles sparged of $\mathrm{O}_{2}$ with $\mathrm{N}_{2}$ gas showed no consumption of $\mathrm{NO}_{2}^{-}$and no production of $\mathrm{N}_{2} \mathrm{O}$.

We next tested whether lower oxygen had an effect on the rates of $\mathrm{NO}_{2}^{-}$or $\mathrm{O}_{2}$ consumption or $\mathrm{N}_{2} \mathrm{O}$ production in nonmutated S. wittichii RW1. To address this question, S. wittichii RW1 cultures were inoculated with $0,0.3$, or $1 \mathrm{mM} \mathrm{NaNO}_{2}$ at either atmospheric or reduced (ca. 3\%) $\mathrm{O}_{2}$ levels. Cultures initiated at atmospheric $\mathrm{O}_{2}$ and $1 \mathrm{mM} \mathrm{NaNO} \mathrm{N}_{2}$ consumed $\mathrm{O}_{2}$ and $\mathrm{NO}_{2}^{-}$significantly faster than cultures initiated at reduced $\mathrm{O}_{2}$ and $1 \mathrm{mM} \mathrm{NaNO}$, yet the rate of $\mathrm{N}_{2} \mathrm{O}$ production was 2-3 times faster for cultures initiated at reduced relative to atmospheric $\mathrm{O}_{2}$ levels (Table 4). The $\mathrm{N}_{2} \mathrm{O}-\mathrm{N}$ measured in the gas headspace of the cultures was orders of magnitude lower than the amount of $\mathrm{NO}_{2}^{-}$consumed per unit biomass (i.e., $n m o l \mathrm{~N}_{2} \mathrm{O}$ produced from $\mu \mathrm{mol} \mathrm{NO}_{2}^{-}$consumed). Even though $\mathrm{N}_{2} \mathrm{O}$ is highly soluble, the vast difference between $\mathrm{NO}_{2}^{-}$consumption and $\mathrm{N}_{2} \mathrm{O}$ production implies conversion of $\mathrm{NO}_{2}^{-}$into a product other than $\mathrm{N}_{2} \mathrm{O}$; however, $\mathrm{NO}_{3}^{-}$was undetectable and $\mathrm{NH}_{4}^{+}$ levels did not vary in any culture at any time point (data not shown). 
Table 3 | Consumption of nitrite and oxygen and production of nitrous oxide by wild-type and $n o r Z_{\text {ch }}$ mutant cultures of $S$. wittichii RW1 initiated at atmospheric oxygen headspace and with 0.3 or $1 \mathrm{mM} \mathrm{NaNO}$.

\begin{tabular}{|c|c|c|c|c|c|c|c|c|c|c|c|c|}
\hline \multirow[t]{2}{*}{ Time (h) } & \multicolumn{4}{|c|}{$\mathrm{NO}_{2}^{-}$remaining (mM) } & \multicolumn{4}{|c|}{$\% \mathrm{O}_{2}$ remaining in the headspace } & \multicolumn{4}{|c|}{$\mathrm{N}_{2} \mathrm{O}$ produced $\left(\mathrm{nmolOD}^{-1}\right)$} \\
\hline & $0.3 \mathrm{mM}$ & $1.0 \mathrm{mM}$ & $0.3 \mathrm{mM}$ & $1.0 \mathrm{mM}$ & $0.3 \mathrm{mM}$ & $1.0 \mathrm{mM}$ & $0.3 \mathrm{mM}$ & $1.0 \mathrm{mM}$ & $0.3 \mathrm{mM}$ & $1.0 \mathrm{mM}$ & $0.3 \mathrm{mM}$ & $1.0 \mathrm{mM}$ \\
\hline 48 & $0.24^{\mathrm{ab}}$ & $0.78^{a}$ & $0.27^{\mathrm{ab}}$ & $0.79^{a}$ & $7.24^{\mathrm{ab}}$ & $7.62^{a}$ & $7.82^{b}$ & 7.55 & $2.66^{\mathrm{ab}}$ & $3.19^{a b}$ & $1.76^{\mathrm{ab}}$ & $2.40^{\mathrm{ab}}$ \\
\hline 72 & $0.01^{\mathrm{a}}$ & $0.24^{\mathrm{ab}}$ & $0.04^{\mathrm{a}}$ & $0.33^{\mathrm{ab}}$ & $4.50^{\mathrm{b}}$ & 4.65 & $4.71^{b}$ & 4.63 & $10.30^{\mathrm{ab}}$ & $34.68^{a b}$ & $8.80^{\mathrm{ab}}$ & $24.99^{a b}$ \\
\hline
\end{tabular}

Values represent averages from 5 experiments initiated on different cultures and on different days. $\mathrm{N}_{2} \mathrm{O}$ amounts were normalized to OD of each culture at each time point. Statistically significant differences between treatments were determined by Student's t-test at $p<0.05$ and are designated as follows:

a Significant difference between 0.3 and $1 \mathrm{mM} \mathrm{NaNO} 2$ treatment groups of wildtype (WT) or nor $Z_{\text {ch }}$ mutant cultures of S. wittichii RW1 at each time point.

${ }^{b}$ Significant difference between $W T$ and nor $Z_{\text {ch }}$ mutant $S$. wittichii RW1 cultures incubated with $0.3 \mathrm{mM} \mathrm{NaNO} 2$ or $1 \mathrm{mM} \mathrm{NaNO}_{2}$.

Table 4 | Maximum rates of nitrite and oxygen consumption and nitrous oxide production by stationary phase S. wittichii RW1 wildtype cultures grown at atmospheric (ca. $22 \%$ ) or reduced (ca. $3 \%$ ) $\mathrm{O}_{2}$ headspace.

\begin{tabular}{|c|c|c|c|c|c|c|}
\hline \multirow[t]{2}{*}{$\begin{array}{l}\mathrm{NaNO}_{2}(\mathrm{mM}) \text { added } \\
\text { to growth medium }\end{array}$} & \multicolumn{2}{|c|}{$\begin{array}{l}\text { Rate of } \mathrm{O}_{2} \text { consumption } \\
\left(\% \text { headspaceOD-1 } h^{-1}\right)\end{array}$} & \multicolumn{2}{|c|}{$\begin{array}{c}\text { Rate of } \mathrm{NO}_{2}^{-} \text {consumption } \\
\left(\mu \mathrm{molOD}^{-1} \mathrm{~h}^{-1}\right)\end{array}$} & \multicolumn{2}{|c|}{$\begin{array}{l}\text { Rate of } \mathrm{N}_{2} \mathrm{O} \text { production } \\
\left(\mathrm{nmolOD}-1 h^{-1}\right)\end{array}$} \\
\hline & Atmos. $\mathrm{O}_{2}$ & Red. $\mathbf{O}_{2}$ & Atmos. $\mathrm{O}_{2}$ & Red. $\mathbf{O}_{2}$ & Atmos. $\mathrm{O}_{2}$ & Red. $\mathbf{O}_{2}$ \\
\hline 0 & 0.03 & 0.02 & 0 & 0 & 0 & 0 \\
\hline 0.3 & 0.03 & 0.02 & 0.9 & 0.9 & $5.2^{*}$ & $16.1^{*}$ \\
\hline
\end{tabular}

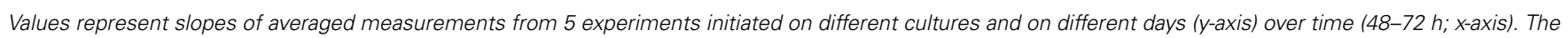
"*" indicates a significant difference between incubations initiated at atmospheric or reduced (3\%) $\mathrm{O}_{2}$ headspace as determined by Student's t-test ( $\left.p<0.05\right)$. Calculated rates of were normalized to $O D$ units of the cultures due to the difference in maximum biomass between cultures (Table 2).

EXPRESSION LEVELS OF PUTATIVE AEROBIC DENITRIFICATION GENES

Levels of specific mRNAs encoding nirK, hmp $p_{\mathrm{p}}$, nor $Z_{\mathrm{ch}}$, and nor $Z_{\mathrm{p}}$, as normalized to levels of $16 \mathrm{~S}$ rRNA, were compared between WT and nor $Z_{\mathrm{ch}}$ mutant $S$. wittichii RW1 from mid-log and into stationary phase $(24-66 \mathrm{~h})$. This period of time covers the interval over which consumption of $\mathrm{NO}_{2}^{-}$and production of $\mathrm{N}_{2} \mathrm{O}$ is measurably active. Expression of nor $Z_{\mathrm{p}}$ substituted for $n o r Z_{\mathrm{ch}}$ in the nor $Z_{\mathrm{ch}}$ mutant strain and the levels of respective nor $Z$ transcript remained relatively high in both cell lines over time (Figure 2). Levels of nirK and $h m p_{\mathrm{p}}$ transcript were significantly higher in the nor $Z_{\mathrm{ch}}$ mutant than in the WT strain at nearly all time points. Whereas nirK and $h m p_{\mathrm{p}}$ transcript levels increased between 24 and $66 \mathrm{~h}$ in WT cells, both transcript levels remained relatively high in the nor $Z_{\mathrm{ch}}$ mutant over the full time course (Figure 2).

Finally, the effect of $\mathrm{NO}_{2}^{-}$on transcript levels was examined in nor $Z_{\mathrm{ch}}$ mutant and WT cultures, and for non-mutated cultures initiated under atmospheric and reduced $\mathrm{O}_{2}$ levels. Each hybridization signal was normalized to that for 16S rRNA, after which the ratio of hybridization intensity between $\mathrm{NaNO}_{2}$ treated and untreated sample was calculated for every culture and each transcript pool. There was no significant effect of $\mathrm{NO}_{2}^{-}$ treatment on any transcript level for any culture until late log phase (i.e., $24 \mathrm{~h}$ for $\mathrm{WT}$ and nor $Z_{\mathrm{ch}}$ mutant cultures and $20 \mathrm{~h}$ for
WT cultures initiated at reduced $\mathrm{O}_{2}$ ). At least a two-fold increase between $\mathrm{NaNO}_{2}$-treated and untreated cells was considered a significant effect; thus, nirK and $h m p$ p were positively responsive to $\mathrm{NaNO}_{2}$ in both WT and nor $Z_{\mathrm{ch}}$ mutant cultures (Table 5). For both nor $Z$ genes, only transcription levels of nor $Z_{\mathrm{p}}$ in the nor $Z_{\mathrm{ch}}$ mutant were responsive to $1 \mathrm{mM} \mathrm{NaNO}_{2}$ treatment.

\section{DISCUSSION}

\section{SPHINGOMONAS WITTICHII RW1 DENITRIFIES NO-- TO $\mathrm{N}_{2} \mathrm{O}$}

Rapid consumption of $\mathrm{NO}_{2}^{-}$by $S$. wittichii RW1 occurred only once the cells reached stationary phase (Table 3 ), suggesting that S. wittichii RW1 performs this process for detoxification or maintenance metabolism rather than for generating proton motive force for cellular growth. During growth under reduced $\mathrm{O}_{2}$, an increased rate of $\mathrm{NO}_{2}^{-}$conversion to $\mathrm{N}_{2} \mathrm{O}$ (Table 4) relative to cultures initiated at atmospheric $\mathrm{O}_{2}$ implies that $\mathrm{O}_{2}$ limitation must be reached for denitrifying activity to commence as would be commonly expected (Zumft, 1997). It is interesting that a faster rate of $\mathrm{NO}_{2}^{-}$consumption occurred for cultures initiated at atmospheric than at reduced $\mathrm{O}_{2}$ in the presence of $1 \mathrm{mM} \mathrm{NaNO}_{2}$ as this implies an additional process from denitrification for $\mathrm{NO}_{2}^{-}$ loss. Although a substantial quantity of $\mathrm{NO}_{2}^{-}$consumed by $S$. wittichii RW1 was converted to $\mathrm{N}_{2} \mathrm{O}$, there was a considerable pool of transformed $\mathrm{NO}_{2}^{-}$that could not be accounted for in $\mathrm{NH}_{4}^{+}$ 


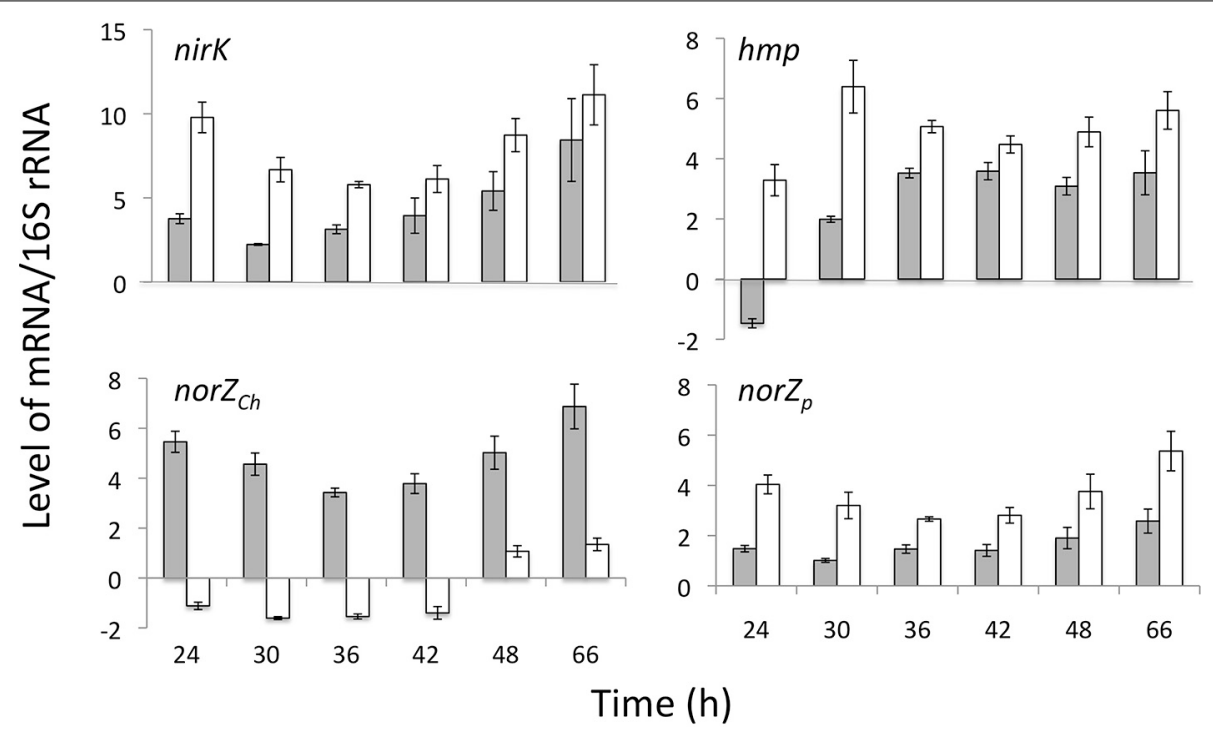

FIGURE 2 | Levels of mRNA of select genes in $\boldsymbol{S}$. wittichii RW1 WT (gray bars) and nor $\boldsymbol{Z}_{\text {ch }}$ mutant (white bars) in batch cultures over time. Error bars represent standard error for 5 replicate experiments performed with separate cultures on different days.

Table 5 | Effect of nitrite and $\mathrm{O}_{2}$ on levels of specific transcripts of $S$. wittichii RW1 from mid-log and early stationary phase cultures.

\begin{tabular}{|c|c|c|c|c|c|c|c|c|c|c|c|c|}
\hline \multirow[t]{2}{*}{ mRNA } & \multicolumn{4}{|c|}{ WT (atmospheric $\mathrm{O}_{2}$ ) } & \multicolumn{4}{|c|}{ WT $\left(\right.$ reduced $\left.\mathrm{O}_{2}\right)$} & \multicolumn{4}{|c|}{ nor $Z_{\text {ch }}\left(\right.$ atmospheric $\left.\mathrm{O}_{2}\right)$} \\
\hline & $24 \mathrm{~h}$ & $36 \mathrm{~h}$ & $24 h$ & $36 \mathrm{~h}$ & $20 \mathrm{~h}$ & $24 \mathrm{~h}$ & $20 \mathrm{~h}$ & $24 \mathrm{~h}$ & $24 \mathrm{~h}$ & $36 \mathrm{~h}$ & $24 \mathrm{~h}$ & $36 \mathrm{~h}$ \\
\hline nirk & $1.68^{\mathrm{a}}$ & $1.56^{\mathrm{a}}$ & $3.98^{\mathrm{a}}$ & $2.17^{\mathrm{ab}}$ & $0.89^{a}$ & 0.96 & $2.00^{\mathrm{a}}$ & 1.38 & $1.81^{\mathrm{a}}$ & $2.28^{\mathrm{a}}$ & $4.53^{\mathrm{a}}$ & $1.56^{\mathrm{ab}}$ \\
\hline hmp & 1.23 & 2.20 & $1.24^{\mathrm{b}}$ & 2.52 & $1.26^{\mathrm{a}}$ & $1.47^{\mathrm{a}}$ & $3.89^{\mathrm{a}}$ & $2.65^{\mathrm{a}}$ & $1.18^{\mathrm{a}}$ & 2.28 & $2.00^{\mathrm{ab}}$ & 2.79 \\
\hline
\end{tabular}

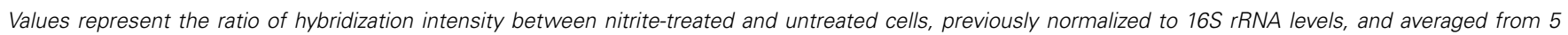

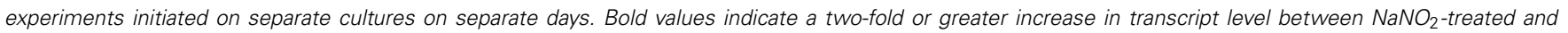
untreated cells. Statistically significant differences between treatments were determined by Student's t-test at $p<0.05$ and are designated as follows:

a Significant difference between 0.3 and $1 \mathrm{mM} \mathrm{NaNO}{ }_{2}$ treatment groups of wild-type (WT) or nor $Z_{\text {ch }}$ mutant cultures of S. wittichii RW1 at the same time point.

${ }^{b}$ Significant difference between $\mathrm{WT}$ and nor $\mathrm{Z}_{\text {ch }}$ mutant cultures initiated at atmospheric $\mathrm{O}_{2}$, incubated with 0.3 or 1 mM NaNO${ }_{2}$.

or $\mathrm{NO}_{3}^{-}$pools. There is no homolog for nitrous oxide reductase (nos $Z$ ) in the genome sequence of $S$. wittichii RW1; hence, denitrification to $\mathrm{N}_{2}$ is unlikely. Sphingomonads are also not known to produce N-storage polymers, but $S$. wittichii RW1 does encode an assimilatory nitrite reductase (nirBD; Swit_1707-8). Thus, the fate of the remaining $\mathrm{NO}_{2}^{-}-\mathrm{N}$ remains unknown.

\section{GENES FOR NITROGEN OXIDE TRANSFORMATIONS ARE EXPRESSED IN $S$. WITTICHII RW1, AND THE nOrZ GENES ARE ISOFUNCTIONAL}

Levels of nirK and $h m p_{\mathrm{p}}$ and either $n o r Z_{\mathrm{ch}}$ (WT) or $n o r Z_{\mathrm{p}}$ (nor $Z_{\mathrm{ch}}$ mutant) transcripts remained relatively high through stationary phase of S. wittichii RW1 (Figure 2), supporting the stationary phase onset of denitrifying activity (Table 3 ). The absence of nor $Z_{\text {ch }}$ expression in $S$. wittichii RW1 had the effects of increasing the exponential growth rate and preventing slowed growth upon exposure to $\mathrm{NO}_{2}^{-}$(Figure 1 and Table 1). This phenotype may be in part due to increased expression of genes for handling nitrosative stress, that is nirK, $h m p_{\mathrm{p}}$, and $n o r Z_{\mathrm{p}}$, in the $n o r Z_{\text {ch }}$ mutant compared to the WT (Figure 2). The increase in transcript pools corresponded to a decrease in the amount of $\mathrm{NO}_{2}^{-}$converted to $\mathrm{N}_{2} \mathrm{O}$ (Table 3), further suggesting that the nor $Z_{\text {ch }}$ mutant cells were not as susceptible to nitrosative stress as the WT. While other unexamined genetic factors were likely at play in mediating these phenotypes of the nor $Z_{\mathrm{ch}}$ mutant, the present data clearly show that the loss of nor $Z_{\mathrm{ch}}$ expression was compensated for by expression of nor $Z_{\mathrm{p}}$; hence, the nor $Z$ genes of S. wittichii RW1 are isofunctional. As with the WT cells, expression of both nirK and $h m p_{\mathrm{p}}$ genes were positively affected by exposure to $\mathrm{NO}_{2}^{-}$in the nor $Z_{\mathrm{ch}}$ mutant (Table 5). This increased expression was potentially a function of nirK and $h m p$ p genes being regulated by NsrR (Swit_1789) and NnrR (Swit_5204) NO responsive regulators, respectively. In addition, the increased level of nor $Z_{\mathrm{p}}$ transcript in the nor $Z_{\mathrm{ch}}$ mutant upon exposure to $1 \mathrm{mM} \mathrm{NaNO}$ (Table 5), suggests a conditional co-regulation 
of hmp-orf1-orf2-nor $Z$ genes when nor $Z_{\mathrm{p}}$ expression is required.

\section{CONCLUSIONS}

Results from this study confirm the ability of S. wittichii RW1 to reduce $\mathrm{NO}_{2}^{-}$to $\mathrm{N}_{2} \mathrm{O}$ and also to transform excess $\mathrm{NO}_{2}^{-}$via another mechanism. This metabolic capability may be restricted to the Spingomonas wittichii species of the sphingomonads based on the limited co-occurrence of nirK and nor $Z$ genes in their genomes. This denitrification module was likely acquired by S. wittichii strains by lateral gene transfer as a function of ecological niche and need for $\mathrm{N}$-oxide detoxification. As meta-'omic studies often rely on correlating functional genes to $16 \mathrm{~S}$ rRNA phylotypes, this study sheds light on the complication of relatively rare LGT events that can confer biogeochemically important functions to individual species of broadly distributed bacterial families.

\section{ACKNOWLEDGMENTS}

This work was supported by the Kearny Foundation for Soil Science and the Environmental Toxicology Program at the University of California, Riverside.

\section{REFERENCES}

Bonamore, A., and Boffi, A. (2008). Flavohemoglobin: structure and reactivity. IUBMB Life 60, 19-28. doi: 10.1002/iub.9

Busch, A., Friedrich, B., and Cramm, R. (2002). Characterization of the norB gene, encoding nitric oxide reductase, in the nondenitrifying cyanobacterium Synechocystis sp strain PCC6803. Appl. Environ. Microbiol. 68, 668-672. doi: 10.1128/AEM.68.2.668-672.2002

Cantera, J. J. L., and Stein, L. Y. (2007). Molecular diversity of nitrite reductase (nirK) genes in nitrifying bacteria. Environ. Microbiol. 9, 765-776. doi: 10.1111/j.1462-2920.2006.01198.x

Chen, J. W., and Strous, M. (2013). Denitrification and aerobic respiration, hybrid electron transport chains and co-evolution. Biochim. Biophys. Acta Bioenerg. 1827, 136-144. doi: 10.1016/j.bbabio.2012.10.002

Clesceri, L. S., Greenberg, A. E., and Eaton, A. D. (1998). Standard Methods for the Examination of Water and Wastewater. Washington, DC: American Public Health Assoc.

Cramm, R., Siddiqui, R. A., and Friedrich, B. (1997). Two isofunctional nitric oxide reductases in Alcaligenes eutrophus H16. J. Bacteriol. 179, 6769-6777.

Fields, S. (2004). Global nitrogen - Cycling out of control. Environ. Health Perspect. 112, A556-A563. doi: 10.1289/ehp.112-a556

Forrester, M. T., and Foster, M. W. (2012). Protection from nitrosative stress: a central role for microbial flavohemoglobin. Free Rad. Biol. Med. 52, 1620-1633. doi: 10.1016/j.freeradbiomed.2012.01.028

Galloway, J. N., Townsend, A. R., Erisman, J. W., Bekunda, M., Cai, Z., Freney, J. R., et al. (2008). Transformation of the nitrogen cycle: recent trends, questions, and potential solutions. Science 320, 889-892. doi: 10.1126/science.1136674

Hendriks, J., Oubrie, A., Castresana, J., Urbani, A., Gemeinhardt, S., and Saraste, M. (2000). Nitric oxide reductases in bacteria. Biochim. Biophys. Acta Bioenerg. 1459, 266-273. doi: 10.1016/S0005-2728(00)00161-4

Householder, T. C., Fozo, E. M., Cardinale, J. A., and Clark, V. L. (2000). Gonococcal nitric oxide reductase is encoded by a single gene, norB, which is required for anaerobic growth and is induced by nitric oxide. Infect. Immunol. 68, 5241-5246. doi: 10.1128/IAI.68.9.5241-5246.2000

Keum, Y. S., Lee, Y. J., and Kim, J. H. (2008). Metabolism of nitrodiphenyl ether herbicides by dioxin-degrading bacterium Sphingomonas wittichii RW1. J. Agricult. Food Chem. 56, 9146-9151. doi: 10.1021/jf801362k

Miller, T. R., Delcher, A. L., Salzberg, S. L., Saunders, E., Detter, J. C., and Halden, R. U. (2010). Genome sequence of the dioxin-mineralizing bacterium Sphingomonas wittichii RW1. J. Bacteriol. 192, 6101-6102. doi: 10.1128/JB.01030-10

Philippot, L., Andert, J., Jones, C. M., Bru, D., and Hallin, S. (2011). Importance of denitrifiers lacking the genes encoding the nitrous oxide reductase for $\mathrm{N}_{2} \mathrm{O}$ emissions from soil. Global Change Biol. 17, 1497-1504. doi: 10.1111/j.13652486.2010.02334.x

Rodionov, D. A., Dubchak, I. L., Arkin, A. P., Alm, E. J., and Gelfand, M. S. (2005). Dissimilatory metabolism of nitrogen oxides in bacteria: comparative reconstruction of transcriptional networks. PLoS Comp. Biol. 1:e55. doi: 10.1371/journal.pcbi.0010055

Rozen, S., and Skaletsky, H. J. (2000). "Primer3 on the WWW for general users and for biologist programmers," in Bioinformatics Methods and Protocols: Methods in Molecular Biology, eds S. Krawetz and S. Misener (Totowa, NJ: Humana Press), 365-386.

Sambrook, J., and Russell, D. W. (2001). Molecular Cloning: a Laboratory Manual. Cold Springs Harbor, NY: Cold Springs Harbor Laboratory Press.

Stein, L. Y. (2011). "Heterotrophic nitrification and nitrifier denitrification," in Nitrification, eds B. B. Ward, D. J. Arp, and M. G. Klotz (Washington, DC: ASM Press), 95-114.

Takaya, N., Kuwazaki, S., Adachi, Y., Suzuki, S., Kikuchi, T., Nakamura, H., et al. (2003). Hybrid respiration in the denitrifying mitochondria of Fusarium oxysporum. J. Biochem. 133, 461-465. doi: 10.1093/jb/ mvg060

Wilkes, H., Wittich, R. M., Timmis, K. N., Fortnagel, P., and Francke, W. (1996). Degradation of chlorinated dibenzofurans and dibenzo-p-dioxins by Sphingomonas sp. strain RW1. Appl. Environ. Microbiol. 62, 367-371.

Wittich, R. M., Wilkes, H., Sinnwell, V., Francke, W., and Fortnagel, P. (1992). Metabolism of dibenzo-para-dioxin by Sphingomonas sp. strain RW1 O. Appl. Environ. Microbiol. 58, 1005-1010.

Yabuuchi, E., Yamamoto, H., Terakubo, S., Okamura, N., Naka, T., Fujiwara, N., et al. (2001). Proposal of Sphingomonas wittichii sp. nov. for strain RW1T, known as a dibenzo-p-dioxin metabolizer. Int. J. Syst. Evol. Microbiol. 51, 281-292.

Zumft, W. G. (1997). Cell biology and molecular basis of denitrification. Microbiol. Mol. Biol. Rev. 61, 533-616.

Conflict of Interest Statement: The authors declare that the research was conducted in the absence of any commercial or financial relationships that could be construed as a potential conflict of interest.

Received: 06 May 2014; accepted: 17 July 2014; published online: 06 August 2014. Citation: Cua LS and Stein LY (2014) Characterization of denitrifying activity by the alphaproteobacterium, Sphingomonas wittichii RW1. Front. Microbiol. 5:404. doi: 10.3389/fmicb.2014.00404

This article was submitted to Evolutionary and Genomic Microbiology, a section of the journal Frontiers in Microbiology.

Copyright (c) 2014 Cua and Stein. This is an open-access article distributed under the terms of the Creative Commons Attribution License (CC BY). The use, distribution or reproduction in other forums is permitted, provided the original author(s) or licensor are credited and that the original publication in this journal is cited, in accordance with accepted academic practice. No use, distribution or reproduction is permitted which does not comply with these terms. 